\title{
２＼cjkstart摩擦攪拌接合（FSW）の特徵ट 日本における適用状況*
}

\author{
岡村久 宣**

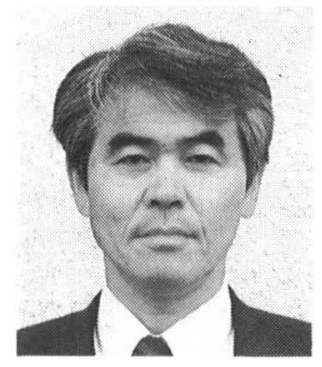

\section{Character of Friction Stir Welding and Apprication in Japan*} \\ by Hisanori OKAMURA** \\ キーワード：摩擦筧汼，塑性流動，アルミニウム合金，鉄道車両，超伝導
} コイル, パラボラアンテナ

\section{1. 緒}

言

昨今の地球の温暖化や環境破壊などに対してその対策 が地球規模で取り組まれている。一方，物造りを本業と する製造メーカーでは, 地球環境に優しい生産技術が求 められている.ところが, 生産技術の中でもその基盤技 術である溶接はアーク, ヒューム, 騒音などの点で悪環 境の代表的職場である。このため, 作業環境の改善や省 工ネが求められている。ささらに製品価格の国際競争の中 で当然, 更なる高品質・低コスト化も同時に求められて いる.

以上のような厳しい状況を打破するためには，これま での延長線上の技術ではなく, 発想の転換が必要であ る。これに応えるかのように, 1991 年, イギリスの公立 の溶接研究所 (TWI) において, これまでの溶接法とは 全く溶接機構が異なる新しい接合法, Friction Stir Welding (FSW) つまり, 摩擦攪抖接合法が開発され $た^{1-3)}$.この接合方法は, 特にアルミニウム合金の溶接上 のこれまでの課題を一挙に解決できる可能性を秘めた接 合法として, 開発と同時に国内外で盛んに応用研究がな され，すでに開発から 7〜8 年の間に製品に適用されつ つある4-11). 現在, この FSW 法はアルミニウム合金を 主体に応用研究が進められている。また, 開発途上の技 術がゆえに公開されていない技術及び適用製品も多々あ ると推察される。このような状況の中で, 本章では, 製 造メ一カで適用する観点からの FSW 法の特徵, アルミ

*原稿受付 平成 12 年 7 月 12 日

**正貝 侏立立製作所日立研究所 Member, Hitachi, Ltd. Hitachi Reseach Laboratory
ニウム合金の製品に適用する場合の接合施工さらに国内 における適用状況並びに今後の展開などについて執者の 経験も交えて述べてみたい。

\section{FSW 法の特徵}

FSW 法の接合機構及び特徵は, TWI の福田氏が担 当されているので詳細は省略する. 本章では製造メーカ における観点からその特徴を述べる.

FSW 法は図 1 に示すように, ボールペンほどの金属 棒の先端にそれよりわずかに細いピンの付いている回転 ツールを回転させながら接合材の突合せ部に挿入し,こ れを回転した状態で接合線に添って移動する。このと き, 接合材は回転ツールとの摩擦熱により軟化し, 更に ツールの回転に引きずられるように塑性流動が生じて接 合される。接合部の温度はアルミ合金の場合, $500^{\circ} \mathrm{C}$ 程 度でアルミ合金の融点 $\left(600 \sim 660^{\circ} \mathrm{C}\right)$ 以下で接合できる 固相接合である.

以上のように, FSW 法はこれまでの接合方法とは全

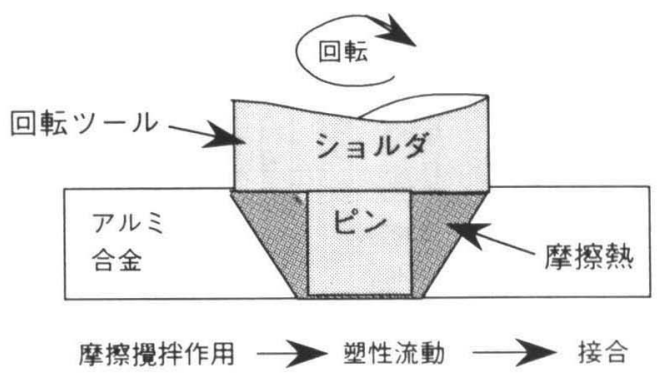

図 1 FSW 法の概要と接合機構 
く接合機構が異なる。このため, 技術面だけでなく, 地 球環境の面でも従来の溶接法では見られない特徵がある. 図 2 に地球環境の観点からまとめた FSW 法の特徴を示す が，環境及び省エネの点でも大きな効果が期待できる。

ただし，次のような短所もあるが，この短所を補うに 余りある効果がある。ささらにこの短所は今後の技術開 発と知恵で対処できる可能性が十分にある.

（1）接合材を強固に拘束する治具が必要

（2）隅肉溶接などが困難で，継手構造が限定される

(3) 継手部のギャップの許容範囲がアーク溶接に比 べて小さい

(4) 接合部の終端に孔が残る

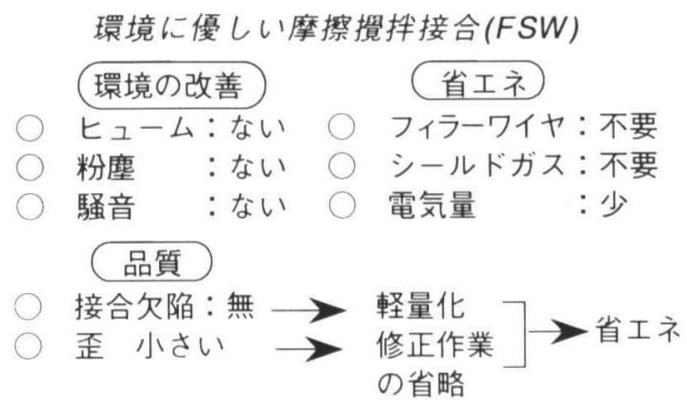

図 2 FSW 法の特幑

\section{3. 接合可能な材料系}

表 1 に FSW で接合の可能な金属材料をまとめて示 す。アルミ合金及びマグネシウム合金は全て接合可能で ある、また，銅系も接合できる。ただし，その組成及び 機械的特性により，接合可能な条件範囲が広い材料と狭
い材料がある。なお，鉄系は TWI では成功しているが， 筆者の経験では極めて困難な材料である。

\section{4. 接 合部の形状}

困 3 に FSW の接合部断面を MIG 溶接部と比較して 示す. FSW 部の表面及び裏面は MIG 溶接部に比べて 極めて平滑である. 従って, FSW の場合は接合のまま で製品に適用できる可能性がある。これも FSWの大き なメリットの一つである.

\section{5. 接合部の温度及びひずみ}

FSW 部の温度測定効果を MIG 溶接部と比較して困 4 に示す. FSW の温度は最高でも $480^{\circ} \mathrm{C}$ で MIG 溶接部

FSW

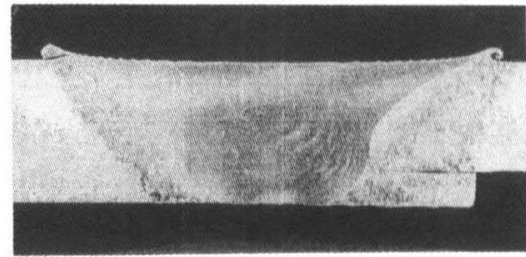

MIG

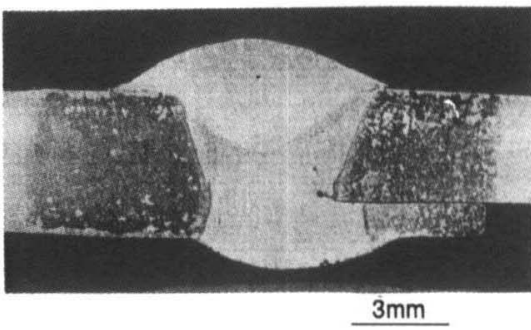

図 3 FSW と MIG 溶接との断面形状の比較

表 1 FSW による各種金属の接合の可能性と条件範囲

\begin{tabular}{|c|c|c|c|c|c|c|}
\hline & \multirow{2}{*}{ 材 質 } & \multirow{2}{*}{ 組 成 } & \multirow{2}{*}{$\begin{array}{l}\text { 厚さ } \\
(\mathrm{mm})\end{array}$} & \multicolumn{2}{|c|}{ 接合性 } \\
\hline & & & & & 接合の可否 & 条件範囲 \\
\hline \multirow{5}{*}{$\begin{array}{c}\text { ア } \\
ル \\
\vdots \\
=\end{array}$} & \multirow{5}{*}{$\begin{array}{l}\text { 非 } \\
\text { 熱 } \\
\text { 処 } \\
\text { 理 } \\
\text { 材 }\end{array}$} & $1080(0)$ & $>99.8 \% \mathrm{Al}$ & \multirow{3}{*}{$\begin{array}{l}1 \sim \\
12.0\end{array}$} & \multirow{3}{*}{$\begin{array}{l}\text { O } \\
\text { 可能 }\end{array}$} & \multirow{3}{*}{$\begin{array}{l}\text { (0) } \\
\text { 㥛めて広い }\end{array}$} \\
\hline & & $1100(\mathrm{H} 14)$ & $>99.0 \% \mathrm{Al}$ & & & \\
\hline & & 3004 (O材) & Al-Mn系 & & & \\
\hline & & 5052 (O材) & \multirow{2}{*}{ Al-Mg系 } & \multirow{2}{*}{$\begin{array}{l}4 \sim \\
12.0\end{array}$} & \multirow{2}{*}{0} & \multirow{2}{*}{$\triangle_{\text {狭い }}$} \\
\hline & & 5083 (O材) & & & & \\
\hline \multirow{5}{*}{$\begin{array}{l}\text { ウ } \\
厶\end{array}$} & \multirow{5}{*}{$\begin{array}{l}\text { 熱 } \\
\text { 処 } \\
\text { 理 } \\
\text { 材 }\end{array}$} & 6061 (T6材) & Al-Si-Mg系 & \multirow{2}{*}{$4 \sim 6$} & \multirow{2}{*}{$\mathrm{O}$} & \multirow{2}{*}{ (O) } \\
\hline & & 6N01 (T5材) & Al-Si-Mg系 & & & \\
\hline & & 2017 (T4材) & Al-Cu-Mg系 & 6.0 & O & $\triangle$ \\
\hline & & 7075 (T6材) & Al-Zn-Mg系 & 6.0 & $\bigcirc$ & $\triangle$ \\
\hline & & 7N01 (T6材) & $\mathrm{Al}-\mathrm{Zn}-\mathrm{Mg}$ 系 & 6.0 & 0 & 0 \\
\hline \multirow{2}{*}{\multicolumn{2}{|c|}{$\begin{array}{l}\text { アルミ } \\
\text { 鋳物品 }\end{array}$}} & 1200FD & $>99 . \%$ & 4.0 & 0 & $\triangle$ \\
\hline & & $5083 F D$ & Al-Mg系 & 6.0 & 0 & $\triangle$ \\
\hline \multicolumn{2}{|c|}{ Mg系 } & MC1 & Al-Mn-Zn系 & 3.0 & 0 & $\triangle$ \\
\hline \multicolumn{2}{|c|}{ 銅系 } & 無酸素鋼 & $>99.99 \%$ & 5.0 & 0 & $\triangle$ \\
\hline \multirow{2}{*}{\multicolumn{2}{|c|}{ 鉄系 }} & 炭素網 & $0.1 \mathrm{C}-0.3 \mathrm{Si}-0.5 \mathrm{Mr}-\mathrm{Fe}$ & \multirow{2}{*}{3.0} & \multirow{2}{*}{$\begin{array}{c}X \\
\text { 困難 }\end{array}$} & \\
\hline & & ステンレス鋼 & $18 \mathrm{Cr}-8 \mathrm{Ni}-\mathrm{Fe}$ & & & \\
\hline
\end{tabular}


の温度 $\left(>660^{\circ} \mathrm{C}\right)$ に比へて極めて低い.

図 5 に同一条件で拘束して溶接した場合の FSWMIG, YAGレーザーの溶接角変形量の比較を示す，材質，厚 さ, 接合材料にもよるが, FSW の角変形は MIG の 1/ $20 \sim 1 / 30$ 程度小さい.これは図 4 に示したように接合部 の温度が低いためで，これも大きな特長である。

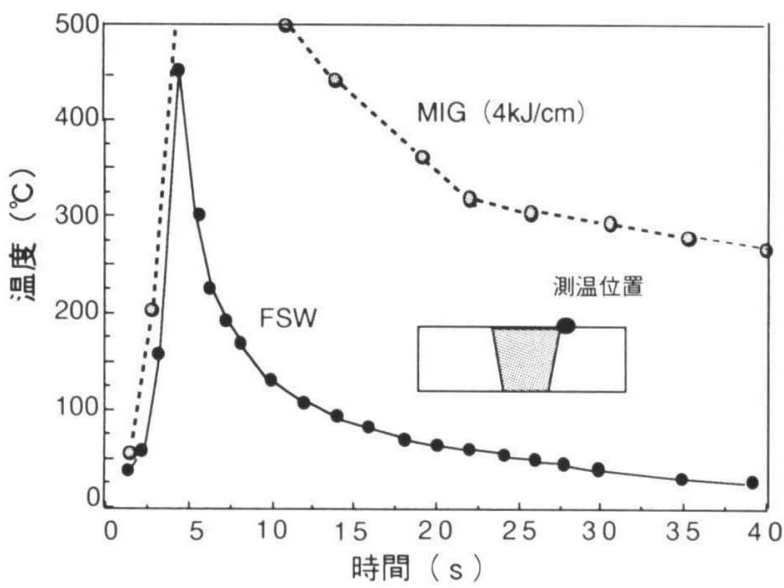

図 4 FSW と MIG との接合部の温度比較 $(6 \mathrm{~N} \mathrm{01-4} \mathrm{mm)}$

\section{6. 接合部の金属的・機械的特性}

日本では特に 6000 系のアルミ合金をFSWした 接合部の金属的及び機械的特性が多く報告されてい る ${ }^{7-12)}$.その報告によると，この合金は熱処理合金の ため，接合部の機械的特性は母材よりわずかに低下する が，ア一ク溶接部以上である。また，硬さ，組織などの 金属的特性もアーク溶接部に比べて何ら劣る点が見られ ない.

一方, 5000 系についても一部報告されているが, アー ク溶接部に比べて何ら劣る点が見られない, ${ }^{9,10)}$.さらに 2000 系及び 7000 系についても同様に報告されてい $3^{1-4)}$.

\section{7. 接 合 施 工}

\section{1 接合条件因子}

FSW 法の接合条件因子を表 2 に示す。基本的な接合 条件因子は，ツールの形状，ツールの回転数，接合速度，

長さ: $1 \mathrm{~m}$ 、厚さ: $3 \mathrm{~mm}(6061$ 材 $)$
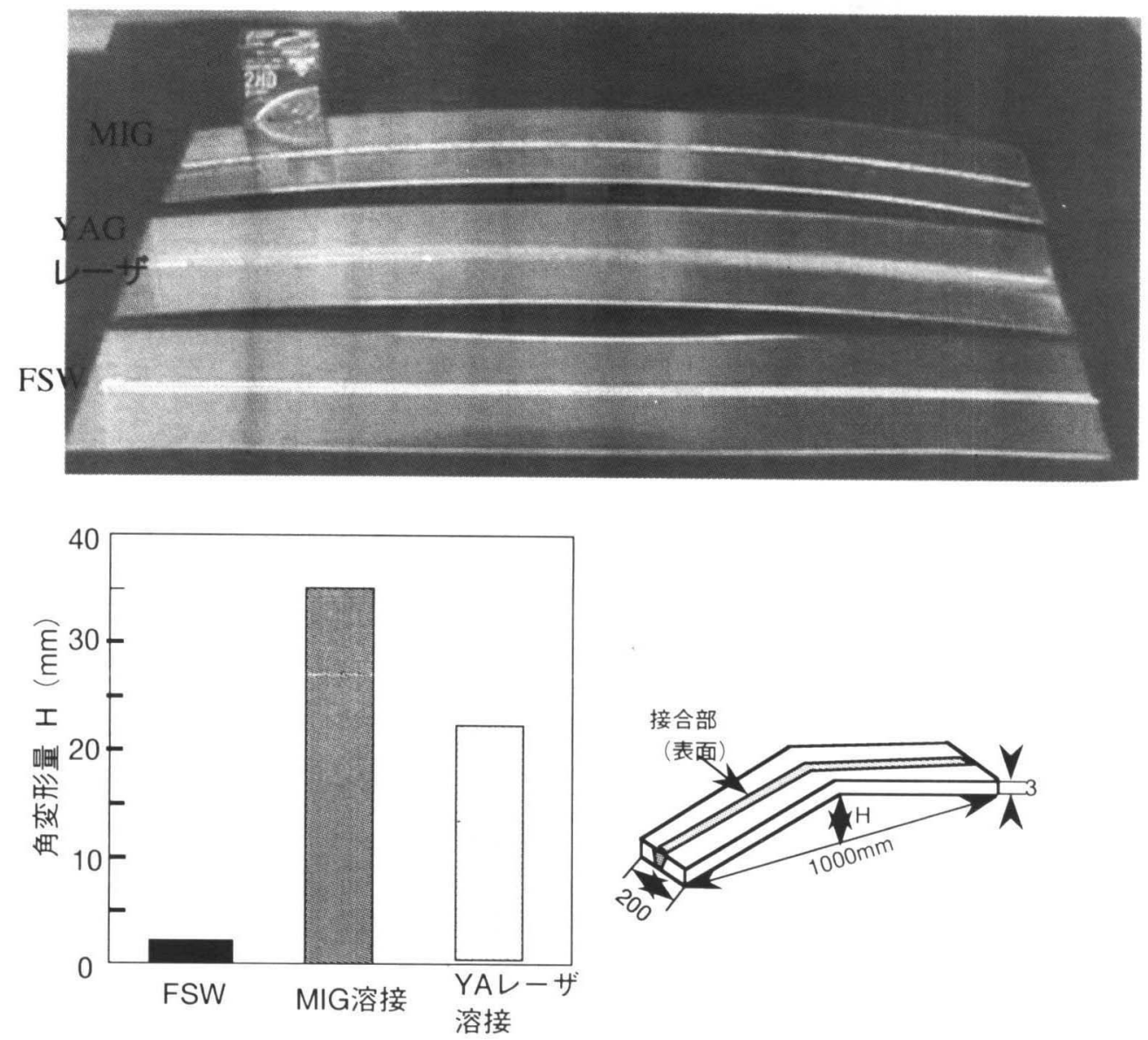

図 $5 \mathrm{FSW} / \mathrm{MIG}$ 溶接/YAG レーザ溶接部の変形状態及び角変形量の比較 $(6061$ 材 厚さ $3 \mathrm{~mm}$, 幅 $200 \mathrm{~mm}$ ，長さ $1000 \mathrm{~mm}$ ) 
表 2 FSW の接合条件因子

\begin{tabular}{|c|c|c|}
\hline \multicolumn{2}{|c|}{ 条件因子 } & 選定のポイント \\
\hline \multicolumn{2}{|c|}{$\begin{array}{l}\text { ツールの形状 } \\
\text { ショルタ径、ビン径 } \\
\text { ビン長さ }\end{array}$} & 材質、形状、厚さにより決定 \\
\hline \multirow{2}{*}{$\begin{array}{l}\text { ツールの } \\
\text { 挿入深さ }\end{array}$} & ピン部 & 接合材の厚さと同等に挿入 \\
\hline & ショル多部 & $\begin{array}{l}\text { 接合材の表面からわずかに } \\
\text { 挿入することが望ましい }\end{array}$ \\
\hline \multicolumn{2}{|c|}{ ツール角度 } & $\begin{array}{l}\text { 若干前進角度を設けること } \\
\text { が望ましい }\end{array}$ \\
\hline \multicolumn{2}{|c|}{ ツール回転数 } & \multirow{3}{*}{ 材質、形状、厚さにより決定 } \\
\hline \multicolumn{2}{|l|}{ 接合速度 } & \\
\hline \multicolumn{2}{|c|}{ 接合材の拘束 } & \\
\hline
\end{tabular}

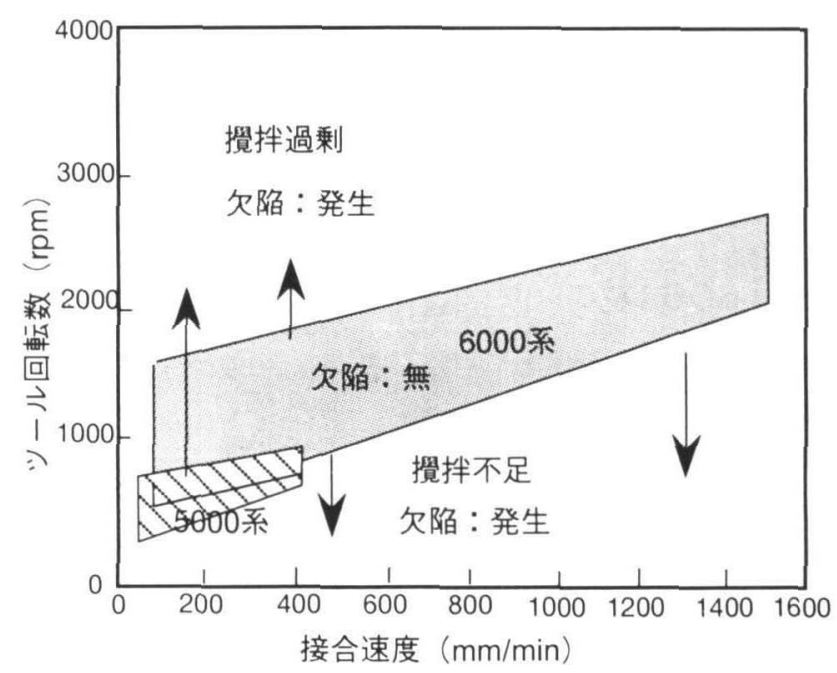

図 6 各アルミ合金の接合条件例（厚さ：5 mm)

接合材の拘束方法である。これらの条件は接合材の材 質，形状，厚さなどにより適宜決定される.

図 6 にアルミ合金 6000 系及U゙ 5000 系の場合の健全な 接合部が得られる接合速度とツールの回転数との関係を 示す. 6000 系の場合は 5000 系に比べて健全な接合部が 得られる条件範囲は極めて広い。ただし, 製品に適用す る場合の条件は, 接合欠陥だけでなく, 接合部の各種特 性, 信頼性, 作業管理基準なども含めて厳密な選定が必 要である。

\section{2 接合部に発生する主な欠陥と头の防止}

FSW は接合材の融点以下で接合できる固相接合のた め, 従来の溶融接合部に発生するような割れやブロー ホールなどの欠宿は発生しない.しかし，次のような接 合条件の場合には欠陥が発生することがある.

図 7 に FSW 部に発生する代表的な欠陥の例を示す。 (a)

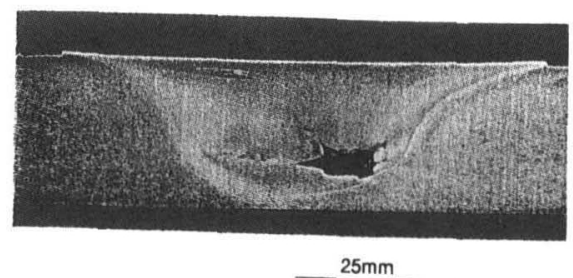

$25 \mathrm{~mm}$

(b)

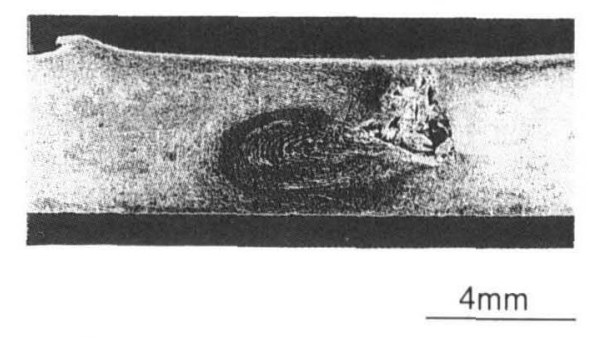

図 7 FSW 部に発生する代表的な欠宿例

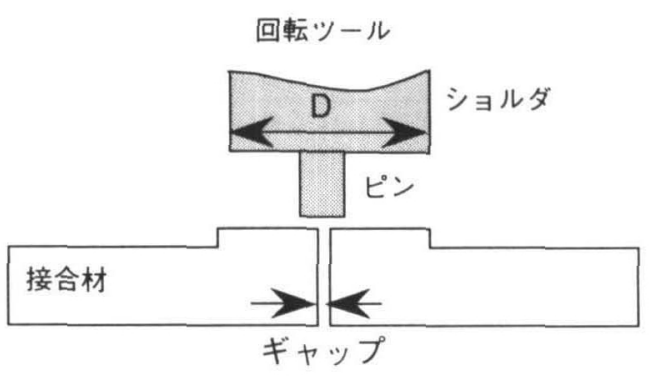

図 8 接合部の継手形状の例

（a）は覴汼不足の場合に発生しやすい代表的な欠陥であ る.これは接合速度に比ぺて回転数が小さい場合及び接 合継手部の開先ギャップが大きい場合などに発生しやす い.（b）は摩擦攪抖が過剩の場合に発生しやすい代表的 な欠陥である，これは接合速度に比べてッールの回転数 が高い場合に発生しやすい.

しかし，接合材質の特性に応じて適正な接合条件であ れば，欠陥のない接合部が再現性よく得られる.

\section{3 接合部の継手形状}

回転ツールはショルダ部とショルダ部より細いピン部 からなっている．ピン部は接合材の中に完全に挿入され るが, ショルダ部もわずかに挿入される。このため, 接 合材の表面がショルダ部で切削されて凹みが生じる、凹 みが生じると接合部の機械的強度の低下原因になるば かりでなく, 製品価值も低下する。そこで, 図 8 に示 すように，子予め接合部に凸を設け，接合中にショルダ で切削して母材表面と同じ高さの平滑にすることが望ま しい.

\section{4 接合部の許容ギャップ}

FSW は溶加材 (フィラワイヤ) を使用しないため, 基 本的にはギャップが無い状態で接合することが望まし い. しかし，接合材が長い場合や加工精度が悪い場合は 接合中にギャップが生じることがある. 


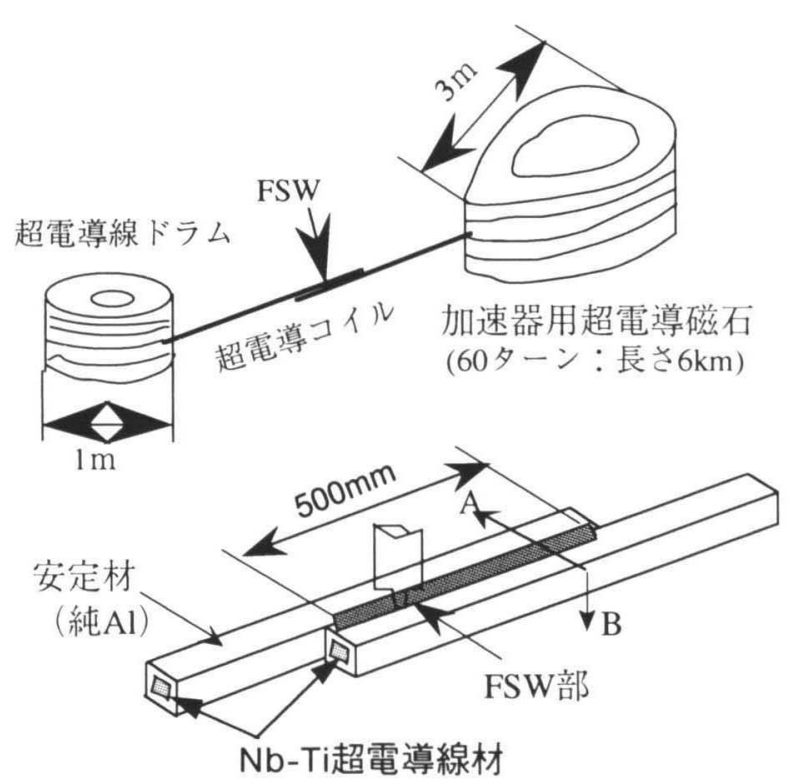

図 9 加速器用超伝導磁石の製作及び FSWによる超伝導 コイル同士の接合状況

継手部にギャップがあると欠陥が発生しやすくなる. 前述の凸型継手はこのギャップを埋める効果もある.

\section{5 接合材表面の管理}

FSW は固相接合のため, 接合材表面の酸化物は接合 部に巻き込まれることが考えられる。しかし，酸化物は ツールの回転により，接合部内に細かく分散されて機械 的強度の低下や気泡などの欠陥に進展するような悪影響 は見られない。このため，特にブラシングなどによる酸 化物の除去が不要である。なお，本 FSW 法は水中でも 接合が不可能である ${ }^{16)}$. この結果からも従来のア一ク溶 接のように, 湿度などの作業環境の厳密な管理は不要で あることが推察できる。

\section{F S W 装 置}

FSW 装置はツールの回転及び上下駆動及び接合方向 移動用の駆動機構, 接合材の拘束機構が基本であるが, その他, 必要に応じて各種の機構が設けられる.これら の駆動機構, 駆動方法及び接合材の拘束用の治具機構は 接合材の構造, 形状, 接合部に要求される特性などで最 適に選定される。

\section{9. 構造物への適用}

以上述べたように, FSW 部には久陥の発生が見られ ないばかりでなく，Uずみ及び金属的，機械的特性は現 状のアーク溶接部に比べて何ら劣る要因は見られず, FSW 部の品質はアーク溶接部以上であると言える.さ らに, アークやヒュームの発生が無く, 作業環境の改善 の点でも大きな効果が期待できる。また, フィラワイヤ 及びシールドガスが不要など省資源効果も期待できる,
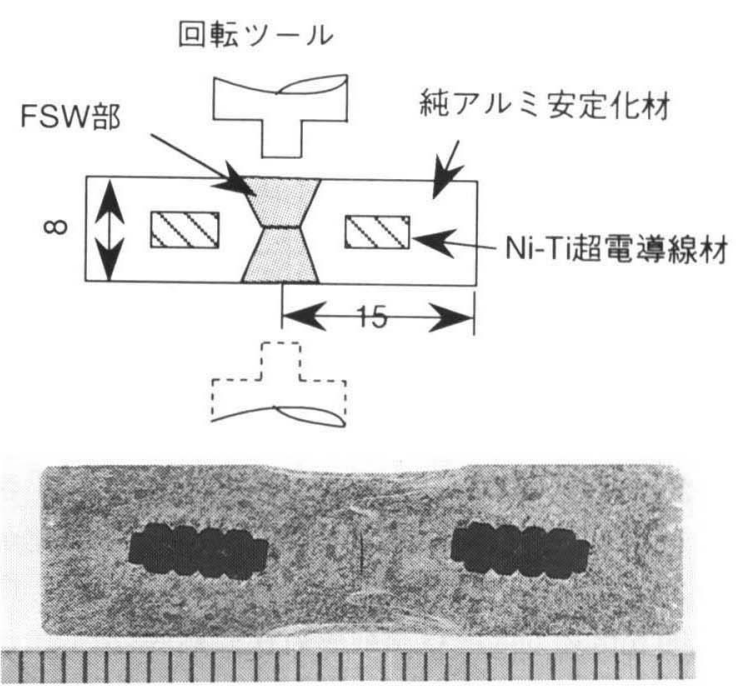

図16のA-B 断面

$15 \mathrm{~mm}$

図 10 FSW で接合した超伝導コイル導体接合の断面

以下，製品への適用例を紹介する.

\section{1 超伝導コイル導体への適用}

図 9 に加速器用の超伝導磁石に超伝導コイルが巻かれ る作業状況及びこの超伝導コイル導体同士を FSW で接 合する概要を示す．超伝導コイルは Nb-Ti の超伝導線 材が純アルミニウムの安定化材 $(8 \times 15 \mathrm{~mm}$ 角) の中に収 められている.この磁石の製作では直径が約 $3 \mathrm{~m}$ の鉄心 の周囲に約 $6 \mathrm{~km}$ の長さの超伝導コイルが巻かれる.こ のため, 途中で超伝導コイル導体同士の接合が必要とな る.この接合は $\mathrm{Nb}-\mathrm{Ti}$ 超伝導線材の熱的劣化を防ぐた め, 純アルミの安定化材同士を $400^{\circ} \mathrm{C}$ 以下の温度で接合 する必要があり, 従来は, はんだ付が採用されていた。 しかし，はんだ付部の強度が低い. はんだ付に銅めっき が必要であるなど作業が煩雑であるため，新しい接合方 法が求められていた。 そこで, この接合に FSWを採用 することにより, Nb-Ti の超伝導線材近傍の温度が $400^{\circ} \mathrm{C}$ 以下で接合でき, かつ, この接合部の液体 $\mathrm{He}$ 中 における超伝導線特性及び機械的強度は全て母材と 同等以上であることを確認している. 図 10 に FSW で接合した超伝導コイル導体同士の接合部断面を示す が, $\mathrm{Nb}$ - Ti の超伝導線材を損傷することなく接合され ている。

\section{2 鉄道車両への適用}

鉄道車再構体は軽量化のためアルミ合金が多く使用さ れている，車両の場合は長尺のアルミ合金の板材を溶接 で組立てる方法で製作され，図 11 に示すように接合部 は直線が多い, また, アルミ合金車両の厚さは $3 \sim 6 \mathrm{~mm}$ と比較的薄いなどで, 特にFSWに適した接合構造であ る5).

困 12 にシングルスキン（リブの付いた平板）及びダ ブルスキン（中リブの付いた中空構造）構造の接合例 と接合部の断面を示す。いずれも従来のアーク溶接で 
組立られた車両に比べて接合部のみならず車両全体 のUずみが大幅に減少し，見栄えのよい車両が製作で きる。

図13に FSW 法で接合した車両の外観を示す8).な お，FSWの場合でもMIG 溶接と同様に接合施工条 件, 品質管理などは澱しく管理される。

\section{3 アルミ合金円筒管への適用}

現在，図 14 に示すようなアルミ円筒管の溶接は MIG 溶接で製作されている。この円筒管の接合に FSW 法が 適用されるならば，1 パス接合が可能でひずみも小さい ため大幅な製造プロセスの簡素化に伴う低コスト化が期 待できる. 図 15 は厚さ $10 \mathrm{~mm}$, 外径が $500 \mathrm{~mm}$, 長さ が $1000 \mathrm{~mm}$ の 5083-O 材の円筒管を FSW 法で接合し た外観を示す．罒に示すように軸方向及円周方向とも 1 パスで接合が可能である.

\section{4 パラボラアンテナへの適用}

現在, 工業用のパラボラアンテナは, 図 16 に示すよ うに, 幅 $1 \mathrm{~m}$, 長さ $3 \mathrm{~m}$ のアルミ合金板材を MIG 溶接 で溶接されている，MIG 溶接の場合，ひずみ取り作業 後, 曲げ加工でアンテナが製作される。これを FSW 法 で接合することにより，接合後のUずみが小さいため, ひずみ取り作業が省略できる. 従って, 高品質化と同時 に低コスト化が期待できる。図 16 に FSW 法で接合し
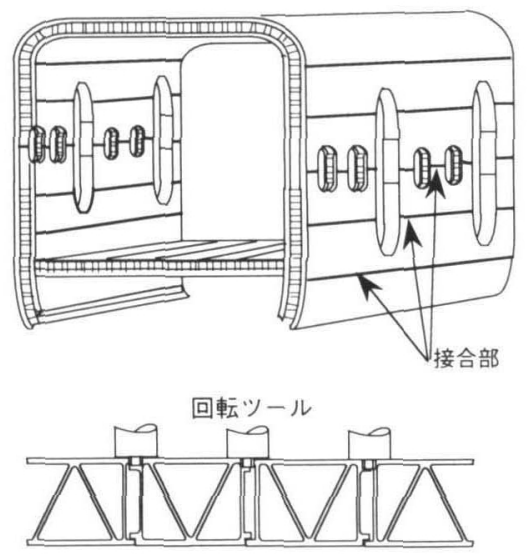

図 11 アルミ合金車两の構造と接合部

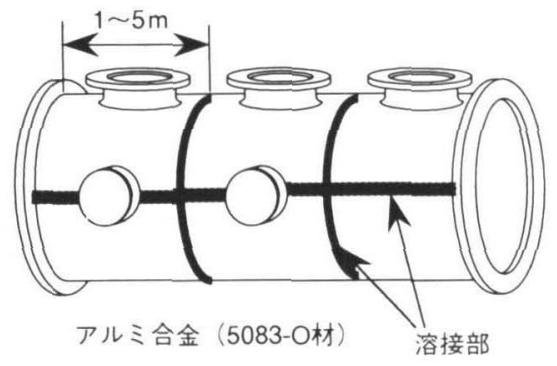

た工業用パラボラアンテナの外観を示す.

\section{0. 品 質 管 理}

アーク溶接に比べて欠宿の発生がなく, 高い品質が得 られる FSW と言えども，接合施工条件の管理をはじめ 超音波探傷試験や X 線当科試験などの非破壊検查法に より，その品質管理はアーク溶接と同等に厳しく管理す ることが望ましい.

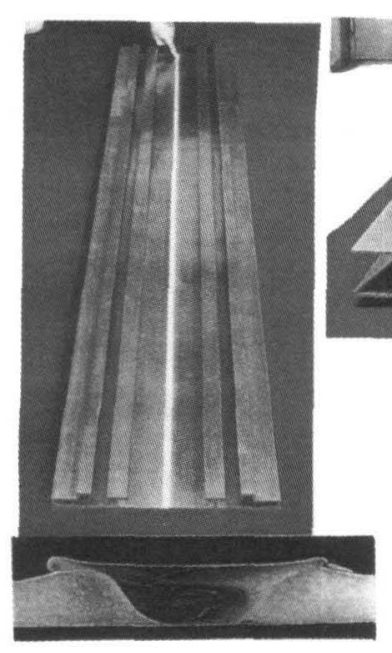

(a) シンダルスキン鯆造 (長さ2 $2 \mathrm{~m}) \quad 5 \mathrm{~mm}$

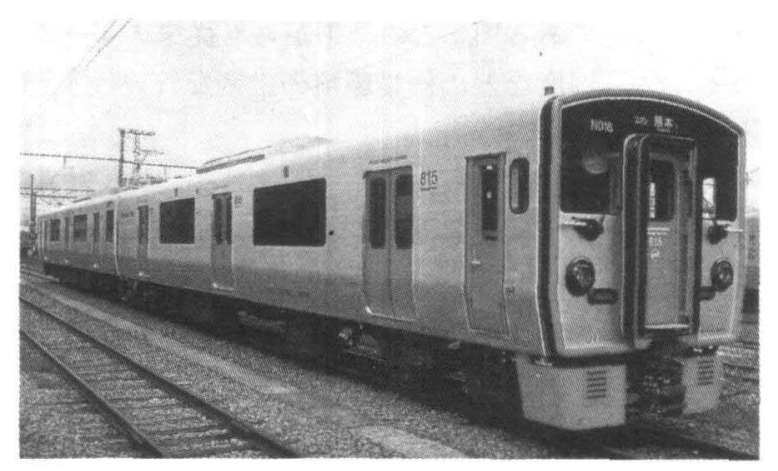

図 13 FSW 法で接合した車両の外観8)

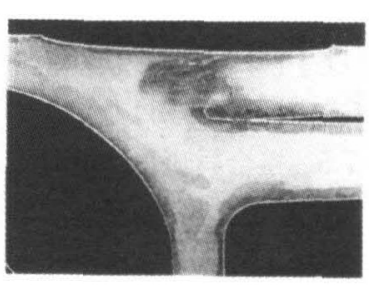

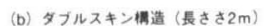

図 12 FSW によるアルミ合金車两部材の接合例

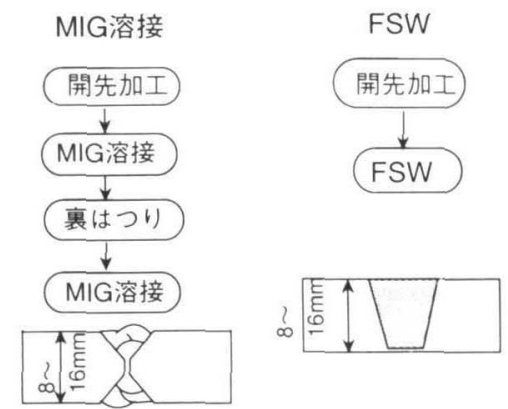

図 14 アルミ合金円筒管の構造及び MIG と FSW との製作プロセスの比較 


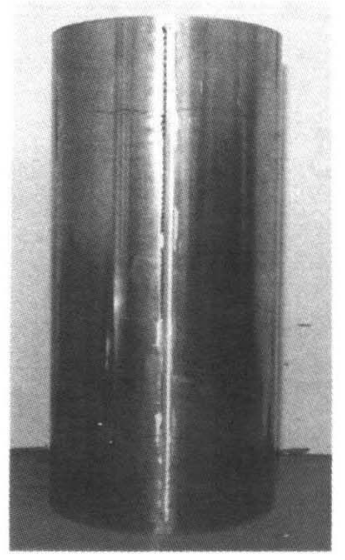

(a) 方向の接合

図 15 FSW によるアルミ合金円筒管の接合例 (5083-O 材, 厚さ : $10 \mathrm{~mm})$
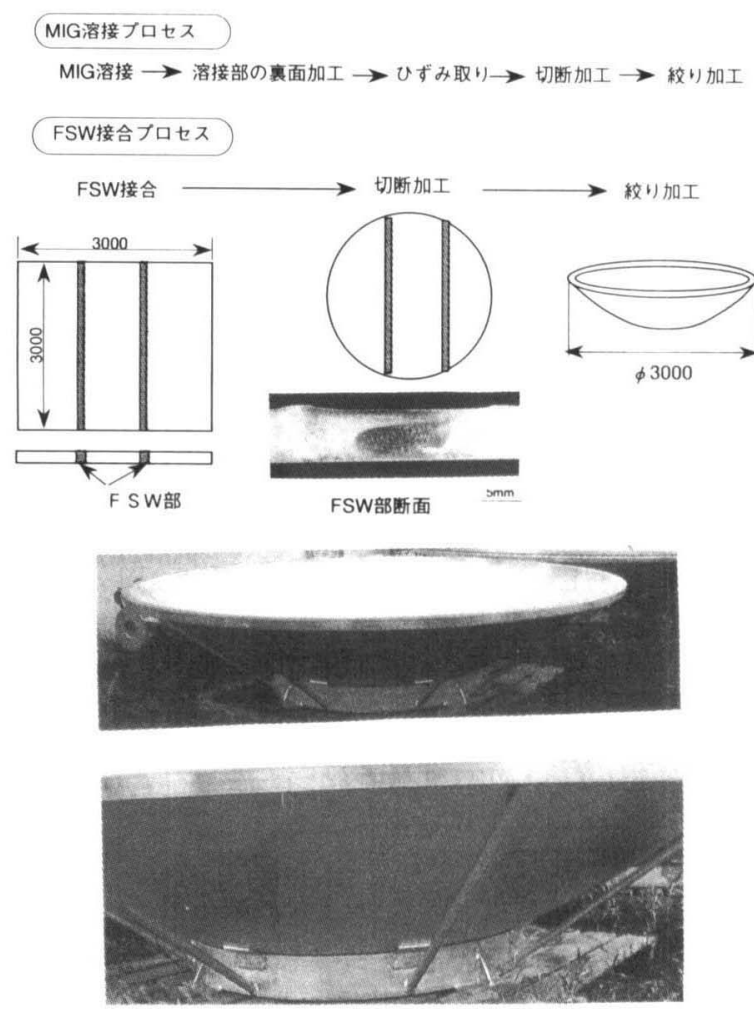

図 16 FSW 法によるパラボラアンテナの接合プロセスと外観

\section{1. 今後の展開及び課題}

FSW は誕生以来, わずか 8９年の歴史が故にまだそ の適用例が少ない.しかし、レーザ溶接に比べるとその スピードは格段に早い. 今後は国内でも自動車, 航空機 器, 船舶, 半導体機器, 民生機器への急速な適用拡大が 予想される。すずに, 欧米では航空, 船舶への適用例が 紹介されている4).
今後, FSWの適用拡大を四るための課題はさらに基 礎的現象の解明及び工業的技術の開発である．基礎的に は接合現象並びに接合部金属的・機械的特性やひずみな どのミクロ的解明が必要である，工業的には FSW の短 所である接合終端部の孔の防止，接合材の拘束の合理 化，隅肉形状などへ適用可能な技術開発が必要である. これらの一部はすでに開発されている技術もあり, 今後 も急速な勢いで開発されるであろう。

\section{2. ま と め}

以上述べたように，FSW はUずみ，金属的及び機械 的特性, 品質, 信頼性は現状のアーク溶接部に比べて優 れている.さらに, アークやヒュームの発生が無く, 作 業環境の改善の点でも大きな効果が期待できた。また， フィラーワイヤ及びシールドガスが不要など省資源効果 も期待できる。しい FSWと言えども FSW が故の本 質的な短所もある。これらの短所をアーク溶接, レーザ 溶接など従来の溶接法で補うことにより，トータルとし て生産技術の一つの強い武器になることが予想される. この武器をいち早く, 利用することが世界的な価格競争 の中で生き残る条件の一つと考える.

\section{参 考 文 献}

1) C.J. Dawes and W.M. Thomas: Friction Stir Joining of Aluminium Alloys; Bulletin No. 61995

2) C.J. Dawes and W.M. Thomas: Friction Stir Prosess Welds Aluminium Alloys; Welding Jounal No. 361995

3) 福田：TWI の摩擦覴拌溶接の実際；溶接技術 7 月号 1999

4) M.R. Johnnsen: Friction Stir Welding Takes off at Boing; Welding Jounal February 1999

5) NIKKEL MECHANICAL No. 5391999.

6) 日本経済新聞：1999 年 10 月 11 日

7）熊谷正樹, 田中 直：摩擦挩拌接合による大型アルミニウ 么素材の製作；軽金属学会第 94 回春期大会講演概要, (1998)

8) 戸取, 岡村：アルミニウム合金の摩擦筧拌接合 (FSW) と 鉄道車両への適用；車両技術，平成 12 年 3 月 No: 219

9）岡村：アルミ合金の摩擦筧抖接合及U゙構造物への適用：溶 接学会 溶接法研究委員会資料平成 11 年 12 月 9 日

10）生島, 堀：FSW の鉄道車两への適用とその品質・強度評 価；軽構造接合加工研究委員会資料 2000 年 1 月 20 日 8) 岡 村：アルミ合金摩擦㹂汼接合部の金属的・機械的特性及びU ずみ；溶接学会 溶接構造研究委員会資料，平成 12 年 6 月 9 日

11) 岡村, 青田, 江角: アルミ合金摩擦䁌拌接合と構造物平成の 適用；軽金属 第 50 巻第 4 号 (2000)

12）田中 直, 谷 正樹：摩摖㩭汼接合した 6 N 01 アルミニウ ム二及ばす時効処理の影響；軽金属学会 第 95 回秋季大会 講演概要, (1998)

13) Peter Ditzel John. C. Lpold: Microstructure Evolution Stir Welding of aluminum Alloy 6061-T 5; EWI Summary Repot SR 9709, November 1997

14) Philip Threadgill: Friction Stir welds in aluminium alloys-preliminary microstructural assessment Bullletin March/April 1997 